\title{
Reluctant Nationalists, Imperial Nation-State, and Neo-Ottomanism: Turks, Albanians, and the Antinomies of the End of Empire - CORRIGENDUM
}

Correction to Nader Sohrabi, 2018, "Reluctant Nationalists, Imperial Nation-State, and Neo-Ottomanism: Turks, Albanians, and the Antinomies of the End of Empire," Social Science History, 2018, 835-870. doi:10.1017/ssh.2018.4

In the acknowledgments section of the above mentioned article, "Holger Afflerbach" was misspelled as "Holger Afflerboch." The correct spelling is "Holger Afflerbach." The author apologizes for the error. 